\title{
PEMBELAJARAN KONTEKSTUAL TIPE HANDS ON ACTIVITY DAN SAVI (SOMATIC, AUDITORY, VISUAL AND INTELECTUAL) UNTUK MENINGKATKAN KEMAMPUAN PEMAHAMAN MATEMATIS SISWA SMP
}

\author{
Rosmaria Sihotang ${ }^{1}$, Sonya F. Tauran ${ }^{2}$ \\ ${ }^{1}$ Sekolah Anak Indonesia Sentul \\ Jl. Werner Schwebig, Kp. Legok Gaok, Desa Kadumangu, Kec. Babakan Madang, \\ Citeureup, Bogor, Jawa Barat \\ ${ }^{2}$ Program Studi Pendidikan Matematika \\ Fakultas Keguruan dan Ilmu Pendidikan \\ Universitas Advent Indonesia \\ Jl. Kolonel Masturi No.288, Parongpong Bandung Barat, Indonesia \\ ${ }^{2}$ sonya.tauran@unai.edu
}

\begin{abstract}
Abstrak. Tujuan dari penelitian ini adalah untuk meningkatkan kemampuan pemahaman matematis siswa SMP melalui penerapan pembelajaran kontekstual tipe Hands on Activity (HOA) dan pembelajaran SAVI (Somatic, Auditory, Visual, and Intelectual). Desain penelitian ini menggunakan kasual komparatif. Sampel penelitian terdiri dari 55 siswa kelas VIII SMPN 10 Cimahi Jawa Barat. Instrumen penelitian adalah instrumen tes dan non-tes. Instrumen tes berupa soal-soal pemahaman matematis tentang bangun ruang sisi datar, dan non tes berupa angket respon siswa terhadap pembelajaran. Uji hipotesis menggunakan uji $\mathrm{t}$ pada taraf signifikan $(\alpha=0,05)$. Hasil dari penelitian menunjukkan bahwa: 1) Kemampuan pemahaman matematis siswa mengalami peningkatan pada kategori sedan, 2) Terdapat perbedaan pada peningkatan kemampuan pemahaman matematis antara siswa yang memperoleh model pembelajaran kontekstual tipe Hands on Activity (HOA) dan siswa yang memperoleh model SAVI (Somatic, Auditory, Visual, and Intelectual, 3) Siswa-siswa memberikan respon suka terhadap model pembelajaran kontekstual tipe Hands on Activity (HOA) dan model pembelajaran SAVI (Somatic, Auditory, Visual And Intelectual).
\end{abstract}

Kata Kunci: Kemampuan Pemahaman Matematis, Hands on Activity (HOA), SAVI (Somatic, Auditory, Visual, and Intelectual)

\section{Pendahuluan}

Matematika adalah ilmu yang sangat penting dalam kehidupan sehari-hari dan dipelajari mulai dari tingkat pendidikan sekolah dasar sampai perguruan tinggi. Haryanto \& Kusmanto (2014) menyatakan bahwa matematika adalah salah satu pelajaran yang diharapkan dapat dikuasai oleh siswa, karena matematika memiliki peranan penting sebagai pembimbing pola pikir maupun sebagai pembentuk sikap.

Salah satu aspek yang membantu siswa dalam belajar matematika adalah pemahaman. Sutisna, Maulana, \& Subarjah (2016) menyatakan bahwa melalui pemahaman matematis akan memberikan pengertian bahwa materi-materi yang diajarkan kepada siswa bukan hanya sebagai hafalan, namun lebih dari itu dengan pemahaman siswa 
dapat lebih mengerti akan konsep materi-materi dalam pelajaran matematika itu sendiri serta pemahaman akan mempermudah siswa untuk mempelajari matematika dengan menyenangkan.

Purwasih (2015) juga menyatakan bahwa pemahaman matematis mampu membantu siswa senantiasa berpikir secara sistematis, mampu menyelesaikan masalah matematika dalam kehidupan sehari-hari dan mampu menerapkan matematika dalam berbagai bidang ilmu pengetahuan. Uraian tersebut menyatakan bahwa pemahaman sangat penting untuk mendukung pembelajaran matematika.

Hasil penelitian yang dilakukan Rusyda \& Sari (2017) terhadap kelas VII SMP Negeri Padang menyatakan bahwa kemampuan pemahaman matematis masih rendah. Hal ini terlihat dari nilai tugas harian siswa dimana cukup banyak siswa yang tidak bisa menyelesaikan soal pemahaman matematis. Mawaddah dan Maryanti (2016) juga menyatakan bahwa kemampuan pemahaman matematis siswa-siswi di SMP Negeri 17 Banjarmasin masih sangat rendah.

Faktor-faktor penyebab rendahnya kemampuan pemahaman matematis diantaranya adalah: (1) Pembelajaran matematika selama ini didominasi oleh guru dan siswa cenderung pasif (Mulyani, 2017); (2) Siswa cenderumg hanya menerima dan mencatat materi yang dijelaskan oleh guru (Rusyda \& Sari, 2017); (3) Kebanyakan guru dalam mengajar masih kurang memperhatikan kemampuan berpikir siswa (Lindawati, 2011); dan (4) Guru kurang mengaitkan pembelajaran matematika dengan kehidupan seharihari (Dini et al, 2018).

Kecakapan guru dalam memilih dan menggunakan model pembelajaran mempengaruhi keberhasilan pembelajaran. Siswa perlu suatu model pembelajaran yang memberikan kesempatan kepada mereka untuk memahami matematika lebih mudah. Dua model yang dapat digunakan untuk mengatasi faktor-faktor penyebab rendahnya kemampuan pemahaman matematis, yaitu dengan menggunakan model pembelajaran kontekstual tipe Hands on Activity (HOA) dan SAVI (Somatic, Auditory, Visual And Intelectual).

Model pembelajaran kontekstual adalah belajar melalui gambaran dari kehidupan nyata sehingga siswa dapat memahami pelajaran matematika melalui kehidupan mereka sendiri. Sejalan dengan pendapat Talbert (Sulianto, 2011) bahwa model pembelajaran kontekstual merupakan konsep belajar yang membantu guru mengaitkan antara materi yang diajarkan dengan situasi dunia nyata siswa dan mendorong siswa membuat hubungan antara pengetahuan yang dimilikinya dengan penerapan dalam kehidupan sehari-hari.

Pembelajaran kontekstual membuat siswa untuk belajar dari apa yang siswa sering lakukan, sehingga membuat siswa lebih aktif dan dapat menemukan konsep pelajaran dengan sendirinya. Pembelajaran kontekstual sangat efektif untuk meningkatkan kemampuan pemahaman matematis siswa. Sejalan dengan pendapat (Amir, 2015) bahwa pembelajaran kontekstual merupakan konsep yang mampu mengaitkan materimateri matematika dengan situasi dunia nyata dan mendorong siswa membuat 
hubungan antara pengetahuan yang dimilikinya dengan penerapannya dalam keidupan sehari-hari.

Hands on Activity (HOA) merupakan suatu model yang dapat meningkatkan kemampuan pemahaman matematis dan dirancang untuk melibatkan siswa dalam menggali informasi dan bertanya, beraktivitas dan menemukan, mengumpulkan data dan menganalisis serta membuat kesimpulan sendiri (Kartono, 2010). Melalui pembelajaran Hands on Activity (HOA) siswa diajak bekerja dengan tangan mereka sendiri dan memalalui itu siswa dapat lebih paham dan dapat memecahkan masalah pelajaran yang sedang mereka hadapi.

Hands on Activity (HOA) akan membantu siswa belajar lebih aktif dan kreatif sehingga siswa tidak hanya menerima dan mencatat materi yang diberikan guru melainkan dapat memahami dan membuat kesimpulan sendiri. Siswa tidak akan merasa bosan karna dalam pembelajaran Hands on Activity (HOA) siswa dituntut untuk selalu aktif dengan pekerjaan tangan yang diberikan oleh guru. Sejalan dengan pendapat Suherman (2003), menyatakan bahwa pembelajaran Hands on Activity (HOA) merupakan pembelajaran yang mengajak siswa belajar dari pengamatan pada kehidupan seharihari yang dapat dikerjakan dengan tangan.

Kegiatan ini menunjang sekali pembelajaran konstektual dengan karakteristik sebagaimana disebutkan oleh Uki, et al. (2017) yaitu: Kerjasama, saling menunjang, gembira, belajar dengan bergairah, pembelajaran terintegrasi, menggunakan berbagai sumber, siswa aktif, menyenangkan, tidak membosankan, sharing dengan teman, siswa kritis dan guru kreatif. Hands On Activity (HOA) akan membentuk suatu penghayatan dan pengalaman untuk menetapkan suatu pengertian (pengetahuan) dan afektif (sikap) yang biasanya menggunakan kerajinan tangan dan atau sejenisnya (Putra, 2017), juga dapat memberikan penghayatan secara mendalam terhadap apa yang dipelajari, sehingga apa yang diperoleh oleh siswa tidak mudah dilupakan.

Kamdi, et al. (2007) berpendapat bahwa Hands On Activity (HOA) membantu siswa dalam memperoleh pengetahuan tersebut secara langsung melalui pengalaman sendiri. Siswa mendapatkan pengalaman terhadap konsep-konsep yang diajarkan oleh guru. Selain untuk membuktikan fakta dan konsep, Hands On Activity (HOA) juga mendorong rasa ingin tahu siswa sehingga cenderung untuk membangkitkan siswa untuk mendapatkan pengamatan dan pengalaman dalam proses pembelajaran. Melalui Hands On Activity (HOA), siswa juga dapat memperoleh manfaat antara lain: Menambah minat, motivasi, menguatkan ingatan, dapat mengatasi masalah kesulitan belajar, menghindarkan salah paham, mendapatkan umpan balik dari siswa serta menghubungkan yang konkrit dan yang abstrak.

Pelaksanaan Hands On Activity (HOA) memperhatikan beberapa hal meliputi: aspek kognitiif, aspek psikomotor dan aspek afektif (Kamdi et al, 2007) menguraikan sebagai berikut: ranah kognitif dapat dilatihkan dengan memberi tugas, memperdalam teori yang berhubungan dengan tugas Hands On Activity (HOA) yang dilakukan, menggabungkan berbagai teori yang telah diperoleh, menerapkan teori yang pernah diperoleh pada masalah yang nyata. Ranah psikomotorik dapat dilatihkan melalui: Memilih, mempersiapkan, dan menggunakan seperangkat alat atau instrumen secara 
tepat dan benar. Ranah afektif dapat dilatihkan dengan cara: merencanakan kegiatan mandiri, bekerja sama dengan kelompok kerja, disipkin dalam kelompok kerja, bersikap jujur dan terbuka serta menghargai ilmunya.

Kamdi et al. (2007), Putra (2017), dan Sucini (2006) menyatakan bahwa kegiatan yang dilakukan adalah:

a. Tahap Persiapan

1. Mengelompokkan siswa sesuai dengan keheterogenan (misalnya berbasis nilai ulangan harian pada bab sebelumnya). Jumlah siswa dalam satu kelas dibagi menjadi beberapa kelompok yang tidak terlalu besar jumlahnya dan memudahkan guru melakukan pengelolaan kelas. Hal ini sangat tergantung dari kondisi riil yang ada.

2. Mempersiapkan bahan praktek yang akan digunakan siswa pada saat pembelajaran berlangsung sekaligus untuk pengerjaan lks.

b. Tahap Pelaksanaan

Pembelajaran Hands on Activity (HOA) dilakukan secara langsung yang bertujuan untuk membangkitkan motivasi siswa yang ditunjukkan dalam aktivitas mereka selama melakukan pengamatan dalam kegiatan pembelajaran. Kegiatan yang dilakukan pada tahap ini adalah:

1. Guru membimbing dan mengarahkan siswa selama pengamatan dalam kegiatan pembelajaran.

2. Siswa dibagi menjadi beberapa kelompok.

3. Setiap kelompok mendapatkan lembar kerja siswa untuk kegiatan praktikum tentang topik tertentu.

4. Melakukan pembelajaran (pengamatan terhadap hasil tindakan dititikberatkan terhadap aktivitas siswa selama melakukan kegiatan pembelajaran).

5. Siswa melakukan diskusi dengan mempresentasikan hasil pengamatan dan membandingkannya dengan kelompok lain, kegiatan pemantapan dilakukan guru terhadap materi pelajaran yang sudah diajarkan dan tes untuk melihat hasil belajar sub bab ini.

c. Tahap Lanjutan

1. Siswa membuat rangkuman dari hasil pengamata.

2. Siswa mengkomunikasikan hasil rangkuman dengan guru bertindak sebagai fasilitator diskusi.

3. Guru memberikan evaluasi.

Tahapan lanjutan adanya tahap lanjutan tersebut, diharapkan hasil belajar siswa dapat tersebut sangat penting sehingga perlu disusun dan direncanakan dengan baik.

Pembelajaran SAVI, yang merupakan akronim dari Somatic, Auditory, Visual, Intelectual, adalah model pembelajaran yang menuntut siswa untuk mendengar, menyimak, berbicara, mempresentasikan, berargumentasi, mengemukakan pendapat, menanggapi serta menggunakan kemampuan berpikir (minds on) pada saat belajar (Meier, 2002). Pembelajaran SAVI akan membuat siswa belajar bergerak aktif secara fisik saat belajar dan belajar menyampaikan pendapat mereka dengan gaya mereka sendiri sehingga menghilangkan rasa bosan ketika sedang belajar. Ini berarti bahwa dalam pembelajaran siswa tidak hanya diam, tetapi beraktivitas dengan menggerakkan seluruh inderanya (Colin, 2002).

Menurut Meier (2002) dan Susilo \& Siswoyuono (2016), pembelajaran SAVI merupakan pembelajaran yang menggabungkan gerakan fisik dengan aktifitas 
intelektual dan penggunaan semua indra dapat berpengaruh besar pada pembelajaran. Ada empat unsur dalam pembelajaran SAVI yaitu Somatis (belajar dengan bergerak dan berbuat), Auditori (belajar dengan mendengar dan berbicara), Visual (belajar dengan mengamati dan menggambarkan) dan Intelektual (belajar memecahkan masalah).

Pembelajaran SAVI mampu menumbuhkan rasa senang dengan penggunaan media warna-warni dan meningkatkan peran siswa dalam pembelajaran matematika (Irawati, 2012). Pembelajaran SAVI mengajak siswa belajar dengan mengunakan seluruh indera sehingga dengan pembelajaran SAVI siswa mampu belajar memahami materimateri matematika yang diberikan guru. Siswa akan menerima pelajaran melalui pemahaman mereka sendiri dan memahami apa yang mereka catat di buku mereka (Astawan, 2013).

Unsur-unsur pembelajaran SAVI yaitu sebagai berikut:

- Belajar Somatis

Somatis berasal dari bahasa Yunani yang berarti tubuh. Belajar somatis berarti belajar dengan indra peraba, kinestesis, praktis-melibatkan dan menggunakan serta menggerakan tubuh sewaktu belajar.

Meier (2002), Susilo \& Siswoyuono (2016) menguatkan pendapatnya dengan menyampaikan hasil penelitian yang mengemukakan bahwa pikiran terdapat diseluruh tubuh. Dari hasil tersebut dapat disimpulkan bahwa dengan menghalangi pembelajaran somatis menggunakan tubuh mereka sepenuhnya.

Untuk merangsang hubungan antara pikiran dan tubuh, suasana belajar harus dapat membuat peserta didik bangkit dan berdiri dari tempat duduknya dan aktif secara fisik dari waktu ke waktu. Misalkan meminta siswa untuk berkelompok, melakukan tindakan yang memerlukan kegiatan fisik seperti siswa diminta maju kedepan untuk menyelesaikan soal yang belum selesai dan melibatkan siswa dalam penggunaan alat peraga.

- Belajar Auditori

Pikiran auditori kita lebih kuat dari pada yang kita sadari. Telinga kita terus menerus menangkap dan menyimpan informasi auditori, bahkan tanpa kita sadari. Dan ketika kita membuat suara sendiri dengan berbicara, beberapa area penting diotak kita menjadi lebih aktif. Kemudian untuk menciptakan suasana pembelajaran yang dapat menarik bagi saluran auditori yang kuat dalam diri siswa, yaitu dengan mengajak siswa membicarakan apa yang sedang dipelajari. Diantaranya yaitu meminta siswa untuk mengajak berbicara saat mereka memecahkan masalah atau meminta siswa berpendapat dan bertanya.

- Belajar Visual

Setiap orang memiliki ketajaman visual yang sangat kuat. Hal ini dikarenakan didalam otak terdapat lebih banyak perangkat untuk memproses informasi visual dari pada dari pada semua indra yang lain. Semisal guru menjelaskan pengertian lingkaran dan memberikan contoh bentuk lingkaran dalam kehidupan sehari-hari. Contoh yang nyata mengenai bentuk kubus yaitu dadu dan kardus berbentuk balok. Dengan begitu siswa lebih mudah menggambarkan tentang pengertian kubus.

- Intelektual

Intelektual merupakan sarana yang digunakan manusia untuk "berpikir". Pada saat belajar, siswa menunjukkan apa yang akan dilakukan dalam pikirannya secara internal, 
ketika mereka menggunakan kecerdasan mereka untuk memecahkan masalah serta merumuskan pertanyaan. Siswa juga belajar untuk berpikir pada saat menjawab pertanyaan dari guru atau saat mengerjakan soal.

Langkah-langkah atau tahapan dalam pembelajaran SAVI menurut Meier (2002) dan Kusumawati (2014) yaitu:

a. Tahap Persiapan (Preparation)

Tahap persiapan berkaitan dengan mempersiapkan siswa untuk belajar. Ini adalah langkah penting yang dilakukan dengan:

1) Melakukan apersepsi dan menjelaskan tujuan pembelajaran (auditori).

2) Membagi kelas dalam beberapa kelompok (somatis).

3) Membangkitkan minat, motivasi dan rasa ingin tahu siwa (auditori).

Tujuan tahap persiapan adalah menimbulkan minat siswa, memberi mereka peranan positif mengenai pengalaman belajar yang akan datang dan menempatkan mereka dalam situasi optimal untuk belajar.

b. Tahap Penyampaian (Presentation)

Tahap ini untuk membantu peserta didik menemukan materi belajar yang baik dengan cara yang menarik dan menyenangkan. Tahap penyampaian dalam belajar bukan hanya sesuatu yang dilakukan fasilitator. Melainkan sesuatu yang secara aktif melibatkan peserta didik untuk menciptakan pengetahuan disetiap langkahnya. Langkah yang dilakukan yaitu dengan:

1. Menyampaikan materi dengan cara memberi contoh nyata (somatis dan auditori).

2. Dari contoh guru menjelaskan materi secara rinci (auditori).

Tujuan tahap ini adalah membantu peserta didik menemukan materi belajar baru dengan cara yang menarik, menyenangkan, relevan, melibatkan panca indera dan cocok untuk semua gaya belajar.

c. Tahap Pelatihan (Practice)

Tahap ini membantu peserta didik mengintegrasikan dan memadukan pengetahuan atau keterampilan baru dengan berbagai cara, yaitu mengajak peserta didik untuk berpikir, berkata-kata dan berbuat mengenai materi baru dengan aktifitas pelatihan pemecahan soal. Langkah yang dilakukan yaitu dengan:

1. Memberikan lembar soal untuk diselesaikan dengan berdiskusi sesuai dengan kelompoknya masing-masing (visual dan intelektual).

2. Meminta beberapa peserta didik mewakili kelompok untuk menampilkan hasil pekerjaannya dan meminta yang lain menanggapi hasil pekerjaan temannya dan memberi kesempatan untuk bertanya (somatis, auditori, visual, intelektual).

3. Menilai hasil pekerjaan siswa dan meralat jawaban apabila terdapat kesalahan terhadap hasil pekerjaannya (auditori).

Tujuan tahap ini adalah untuk membantu siswa mengintegrasi dan menyerap pengetahuan da $\mathrm{n}$ keterampilan baru dengan berbagai cara.

d. Tahap Penampilan (Performance)

Tahap ini membantu siswa menerapkan dan mengembangkan pengetahuan serta keterampilan baru mereka pada pekerjaan, sehingga akan melekat pada siswa, dan prestasi mereka terus meningkat. Langkah yang dilakukan yaitu dengan: 
1. Memberi suatu evaluasi yang berupa lembar soal untuk mengetahui dan mengembangkan tingkat pemahaman serta keterampilan siswa setelah proses pembelajaran (somatis dan intelektual).

2. Menegaskan kembali materi yang telah diajarkan. Kemudian menyimpulkan dan memberikan tugas atau pekerjaan rumah (auditori). Tujuan tahap ini adalah untuk membantu siswa menerapkan dan memperluas pengetahuan atau keterampilan baru mereka pada pekerjaan, sehingga hasil belajar akan selalu melekat dan terus meningkat.

Berdasarkan uraian yang telah dikemukakan, maka tujuan dari studi ini adalah untuk mengetahui: 1) bagaimana peningkatan kemampuan pemahaman matematis siswa yang memperoleh pembelajaran kontekstual tipe Hands on Activity dan Pembelajaran SAVI, 2) Apakah terdapat perbedaan pada peningkatan kemampuan pemahaman matematis antara siswa yang memperoleh model pembelajaran kontekstual tipe Hands on Activity (HOA) dan siswa yang memperoleh model SAVI, 3) Bagaimana respon siswa terhadap pembelajaran kontekstual tipe Hands on Activity dan Pembelajaran SAVI. Penulis menduga bahwa terdapat perbedaan pada peningkatan kemampuan pemahaman matematis antara siswa yang memperoleh model pembelajaran kontekstual tipe Hands on Activity (HOA) dan siswa yang memperoleh model SAVI.

\section{METODE}

Penelitian ini menggunakan desain studi komparatif. Penelitian ini melibatkan dua kelas. Kelas pertama memperoleh model pembelajaran kontekstual Hands on Activity (HOA) dan kelas kedua memperoleh model pembelajaran SAVI (Somatic, Intelectual, Visual,and Intelectual). Populasi dari penelitian ini adalah siswa kelas VIII SMP Negeri 10 Cimahi, Jawa Barat. Sampel dari penelitian ini adalah 30 siswa kelas VIII B dan 25 siswa kelas VIII C yang dipilih secara purposif. Instrumen penelitian yang digunakan adalah instrumen tes dan non tes. Instrumen tes berupa soal uraian kemampuan pemahaman matematis pada pokok bahasan Bangun Ruang Sisi Datar, sedangkan instrumen non tes berupa angket respon siswa. Data yang diperoleh adalah hasil pretes dan postes serta angket respon siswa. Pengelolaan data dengan menggunakan software SPSS untuk melihat peningkatan kemampuan pemahaman matematis siswa yang memperoleh model pembelajaran Hands on Activity (HOA) dan model pembelajaran SAVI (Somatic, Auditory, Visual, and Intelectual).

\section{HASIL PENELITIAN DAN PEMBAHASAN}

Peneliti mendeskripsikan Pretes, Postes, dan Gain kemampuan pemahaman matematis siswa yang memperoleh pembelajaran kontekstual tipe HOA maupun siswa yang memperoleh pembelajaran SAVI. Hasil analisis deskripsi Pretes, Postes, dan Gain kemampuan pemahaman matematis siswa disajikan pada Tabel 4.1.

\section{Tabel 4.1}

Hasil Deskripsi Kemampuan Pemahaman Matematis

\begin{tabular}{|c|c|c|c|c|c|c|}
\hline \multirow{2}{*}{} & \multicolumn{2}{|c|}{ Pretes } & \multicolumn{2}{c|}{ Postes } & \multicolumn{2}{c|}{ Gain } \\
\cline { 2 - 7 } & HOA & SAVI & HOA & SAVI & HOA & SAVI \\
\hline $\mathrm{N}$ & 30 & 25 & 30 & 25 & 30 & 25 \\
\hline Mean & 22,93 & 20,72 & 45,16 & 38,36 & 0,45 & 0,34 \\
\hline Std. Deviation & 6,04 & 5,25 & 9,73 & 9,97 & 0,18 & 0,18 \\
\hline
\end{tabular}


Berdasarkan analisis data pada Tabel 4.1, rata-rata skor pretes kemampuan pemahaman matematis pada kedua kelas tersebut masih termasuk kategori rendah.

Rata-rata skor postes kemampuan pemahaman matematis pada kedua kelas meningkat. Skor Maksimal Ideal (SMI=72). Hasil analisis data gain ternormalisasi menunjukkan bahwa rata-rata gain ternormalisasi pada kelas pembelajaran HOA termasuk kategori sedang, dan rata-rata gain ternormalisasi kelas pembelajaran SAVI termasuk kategori sedang.

Uji Normalitas pretes dilakukan dalam penelitian ini untuk mengetahui apakah data pretes tersebut berdistribusi normal atau tidak. Uji normalitas ini dilakukan menggunakan uji Shapiro-Wilk dengan taraf signifikan 0,05. Hasil uji normalitas pretes yang diperoleh disajikan Pada Tabel 4.2.

Tabel 4.2

Hasil Uji Normalitas Pretes

\begin{tabular}{|l|l|l|l|}
\hline \multirow{2}{*}{ Kelas } & \multicolumn{3}{|c|}{ Shapiro-Wilk } \\
\cline { 2 - 4 } & Statistic & Df. & Sig. \\
\hline Pembelajaran HOA & 0,973 & 30 & 0,622 \\
\hline Pembelajaran SAVI & 0,961 & 25 & 0,425 \\
\hline
\end{tabular}

Berdasarkan Tabel 4.2 terdapat nilai signifkansi pretes siswa pada kedua kelas lebih dari 0,05 maka $\mathrm{H}_{0}$ tidak ditolak, berarti data pretes yang memperoleh pembelajaran HOA dan yang memperoleh pembelajaran SAVI berasal dari populasi yang berdistribusi normal.

Uji homogenitas pretes kemampuan pemahaman matematis siswa dilakukan untuk mengetahui apakah populasi data kemampuan pemahaman kedua kelas memiliki varians populasi yang homogen atau tidak. Hasil uji homogenitas pretes disajikan pada Tabel 4.3.

Tabel 4.3

Hasil Uji Homogenitas Pretes

\begin{tabular}{|l|l|l|l|l|}
\hline & Levene Statistic & df1 & df2 & Sig. \\
\hline Based on Mean & 0,161 & 1 & 53 & 0,690 \\
\hline
\end{tabular}

Berdasarkan Tabel 4.3 hasil dari uji homogenitas menunjukkan bahwa nilai signifikansi adalah 0,690>0,05, maka data pretes siswa yang memperoleh pembelajaran HOA dan pembelajaran SAVI memiliki varians yang homogen.

Uji beda dua rata-rata pretes dilakukan dengan uji statistik parametrik: menggunakan uji-t karena data pretes berasal dari populasi yang berdistribusi normal. Hasil uji beda dua rata-rata pretes disajikan pada Tabel 4.4.

Tabel 4. 4

Hasil Uji Beda Dua Rata-rata Pretes

\begin{tabular}{|c|c|c|c|c|c|c|c|}
\hline & \multicolumn{7}{|c|}{ Independent samples test } \\
\hline & \multirow[t]{2}{*}{$T$} & \multirow[t]{2}{*}{$D f$} & \multirow[t]{2}{*}{$\begin{array}{c}\text { Sig. } \\
(2- \\
\text { tailed })\end{array}$} & \multirow[t]{2}{*}{$\begin{array}{c}\text { Mean } \\
\text { Difference }\end{array}$} & \multirow[t]{2}{*}{$\begin{array}{l}\text { Std. Error } \\
\text { Difference }\end{array}$} & \multicolumn{2}{|c|}{$\begin{array}{l}\text { 95\% Confidence } \\
\text { Interval of the } \\
\text { Difference }\end{array}$} \\
\hline & & & & & & Lower & Upper \\
\hline $\begin{array}{c}\text { Equal } \\
\text { variances } \\
\text { assumed }\end{array}$ & 1,434 & 53 & 0,158 & 2,213 & 1,543 & $-0,883$ & 5,310 \\
\hline
\end{tabular}


Berdasarkan Tabel 4.4 menunjukkan hasil uji beda dua rata-rata data pretes dengan menggunakan Uji-t memperoleh nilai Asymp.Sig. (2-tailed) $=0,158>0,05$ sehingga $\mathrm{H}_{0}$ tidak ditolak. Hal ini menunjukkan tidak terdapat perbedaan yang signifikan pada kemampuan pemahaman matematis siswa sebelum memperoleh pembelajaran HOA dan pembelajaran SAVI. Ini berarti bahwa kemampuan pemahaman matematis siswa pada ke dua kelas sebelum pembelajaran diberikan adalah tidak berbeda.

Uji normalitas Gain Ternormalisasi dilakukan dalam penelitian ini untuk mengetahui apakah data gain ternormalisasi berdistribusi normal atau tidak. Uji normalitas ini dilakukan menggunakan uji Shapiro-Wilk dengan taraf signifikansi $(\alpha)=0,05$. Hasil uji normalitas gain ternormalisasi yang diperoleh disajikan pada Tabel 4.5.

Tabel 4.5

Hasil Uji Normalitas Gain Ternormalisasi

\begin{tabular}{|c|c|c|c|}
\hline \multirow{2}{*}{ Kelas } & \multicolumn{3}{|c|}{ Shapiro-Wilk } \\
\cline { 2 - 4 } & Statistic & df. & Sig. \\
\hline Pembelajaran HOA & 0,973 & 30 & 0,428 \\
\hline Pembelajaran SAVI & 0,961 & 25 & 0,295 \\
\hline
\end{tabular}

Berdasarkan hasil pada Tabel 4.5 menunjukkan bahwa nilai signifikansi pada kelas siswa yang memperoleh pembelajaran HOA adalah 0,428 >0,05, berarti populasi data gain ternormalisasi berdistribusi normal. Sedangkan pada pembelajaran SAVI menunjukkan bahwa nilai signifikansinya adalah $0,295>0,05$, berarti populasi data gain ternormalisasi berdistribusi normal.

Uji homogenitas gain ternomalisasi dilakukan untuk mengetahui apakah populasi data gain ternormalisasi dua kelas memiliki varians populasi yang sama atau tidak. Hasil uji homogenitas gain ternormalisasi disajikan pada Tabel 4.6.

Tabel 4.6

Hasil Uji Homogenitas Gain Ternormalisasi

\begin{tabular}{|l|c|c|c|c|}
\hline & Levene Statistic & df1 & df2 & Sig. \\
\hline Based on mean & 0,048 & 1 & 53 & 0,827 \\
\hline
\end{tabular}

Berdasarkan pada Tabel 4.6 hasil uji homogenitas gain ternormalisasi menunjukkan bahwa nilai signifikansinya $0,827>0,05$ maka kedua populasi data gain ternormalisasi memiliki varians yang sama berdasarkan kriteria uji homogenitas. Untuk mengetahui apakah terdapat perbedaan rata-rata gain ternormalisasi dari kedua kelompok siswa selanjutnya dilakukan uji beda dua rata-rata gain ternormalisasi.

Uji beda dua rata-rata gain ternormalisasi dilakukan dengan uji statistik non parametrik: Mann-Whitney karena data gain ternormalisasi berasal dari populasi yang tidak berdistribusi normal dan memiliki varians yang homogen. Hasil uji beda dua rata-rata gain ternormalisasi disajikan pada Tabel 4.7.

Tabel 4.7

Hasil Uji Beda Dua Rata-rata GainTernormalisasi

\begin{tabular}{|c|c|c|c|c|c|c|}
\hline & \multicolumn{6}{|c|}{ Independent samples test } \\
\cline { 2 - 6 } & $T$ & Df & $\begin{array}{c}\text { Sig. } \\
(2-\end{array}$ & $\begin{array}{c}\text { Mean } \\
\text { Difference }\end{array}$ & $\begin{array}{c}\text { Std. Error } \\
\text { Difference }\end{array}$ & $\begin{array}{c}\text { 95\% Confidence } \\
\text { Interval of the } \\
\text { Difference }\end{array}$ \\
\hline
\end{tabular}




\begin{tabular}{|c|c|c|c|c|c|c|c|}
\hline & & & & & & Lower & Upper \\
\hline $\begin{array}{c}\text { Equal } \\
\text { variances } \\
\text { assumed }\end{array}$ & 2,186 & 53 & 0,033 & 0,107 & 0,048 & 0,008 & 0,205 \\
\hline
\end{tabular}

Berdasarkan Tabel 4.7 menunjukkan signifikansi (2-tailed) $0,033<0,05$. Artinya, Terdapat perbedaan pada peningkatan kemampuan pemahaman matematis antara siswa yang memperoleh pembelajaran kontekstual tipe Hands on Activity (HOA) dan siswa yang memperoleh pembelajaran SAVI (Somatic, Auditory, Visual, and Intelectual).

Rata-rata hasil angket respon siswa terhadap pembelajaran HOA dan SAVI disajikan pada Tabel 4.14.

Tabel 4.14

Hasil Angket Respon terhadap Pembelajaran HOA dan SAVI

\begin{tabular}{|c|c|c|c|c|}
\hline Aspek & HOA & Interpretasi & SAVI & Interpretasi \\
\hline Pembelajaran Matematika & $73,88 \%$ & Suka & $62 \%$ & Suka \\
\hline Kegunaan Matematika & $85 \%$ & Sangat Suka & $82 \%$ & Sangat Suka \\
\hline Aktivitas Siswa & $61,42 \%$ & Suka & $54,85 \%$ & Biasa \\
\hline Peran Guru & $79,33 \%$ & Suka & $89,60 \%$ & Sangat Suka \\
\hline Total Rata-rata & $\mathbf{7 4 , 9 0 \%}$ & Suka & $\mathbf{7 2 , 1 1 \%}$ & Suka \\
\hline
\end{tabular}

Berdasarkan Tabel 4.14 ditunjukkan bahwa hasil angket respon siswa memberikan respon 74,90\% kategori "Suka" terhadap model pembelajaran kontekstual tipe Hands on Activity (HOA) dan 72,11\% kategori "Suka" model pembelajaran SAVI (Somatic, Auditory, Visual And Intelectual).

\section{SIMPULAN}

Berdasarkan hasil penelitian, maka kesimpulan dari penelitian ini adalah Kemampuan pemahaman matematis siswa yang memperoleh pembelajaran Hands on Activity (HOA) dengan siswa yang memperoleh pembelajaran SAVI (Somatic, Auditory, Visual, and Intelectual) mengalami peningkatan pada kategori sedang. Terdapat perbedaan pada peningkatan kemampuan pemahaman matematis antara siswa yang memperoleh pembelajaran kontekstual tipe Hands on Activity (HOA) dan siswa yang memperoleh pembelajaran SAVI (Somatic, Auditory, Visual, and Intelectual). Siswa memberikan respon suka terhadap pembelajaran kontekstual tipe Hands on Activity (HOA) dan model pembelajaran SAVI (Somatic, Auditory, Visual And Intelectual). Hasil penelitian ini dapat menjadi referensi atau bahan perbandingan bagi peneliti lain untuk mengkaji lebih lanjut terhadap pembelajaran kontekstual tipe Hands on Activity (HOA) dan model SAVI (Somatic, Auditory, Visual, and Intelectual) dalam meningkatkan kemampuan pemahaman matematis siswa dan kemampuan matematis lainnya. Guru dapat menggunakan model pembelajaran tipe Hands on Activity

(HOA) dan model SAVI (Somatic, Auditory, Visual, and Intelectual) sebagai alternatif pembelajaran agar siswa tidak monoton dan bosan sehingga kemampuan pemahaman matematis siswa dan kemampuan lainnya dapat meningkat. 


\section{DAFTAR PUSTAKA}

Amir, M. F. (2015). Pengaruh Pembelajaran Kontekstual Terhadap Kemampuan Pemecahan Masalah Matematika Siswa Sekolah Dasar. Prosiding Seminar Nasional Pendidikan, 24 Oktober 2015.

Astawan, I G. 2013. Pengaruh Model Pembelajaran dan Gaya Belajar Terhadap Pemahaman Konsep dan Kemampuan Pemecahan Masalah Siswa kelas IV SD. Jurnal Ilmiah Pendidikan dan Pembelajaran.

Collin, R. (2002). Accelerated Learning for The 21st Century (diterjemahkan oleh: Dedy Ahimsah). Jakarta: Nuansa.

Fitriani, K. \& Maulana, (2016). Meningkatkan Kemampuan Pemahaman Dan Pemecahan Masalah Matematis Siswa SD Kelas V Melalui Pendekatan Matematika Realistik. Mimbar Sekolah Dasar Volume 3 Nomor 1 April 2016.

Irawati, W. R. (2012). Alternatif Pembelajaran Dengan Pendekatan Savi Untuk Meningkatkan Pemahaman Siswa Sd/Mi Terhadap Materi Membandingkan Pecahan Sederhana. Jurnal Pendidikan Dasar, Nomor 12 Maret 2012

Haryanto, H. \& Kusmanto, B. (2014). Penerapan Group To Group Exchange Untuk Meningkatkan Keaktifan dan Hasil Belajar Matematika Siswa Kelas XA SMA Negeri I Tanjung Sari Gunung Kidul. Jurnal Pendidikan Matematika Volume 1 Nomor 3 Juni 2014.

Kamdi, Et al. (2007). Model-Model Pembelajaran Inovatif. Malang: Universitas Negeri Malang

Kartono, (2010). Hands On Activity Pada Pembelajaran Geometri Sekolah Sebagai Asesmen Kinerja Siswa." Kreano, Jurnal Matematika Kreatif-Inovatif 1.1 (2010).

Kusumawati, S. W. (2014). Penerapan Model Pembelajaran Savi Untuk Meningkatkan Keterampilan Pemecahan Masalah Di Sekolah Dasar. Jurnal Penelitian Pendidikan Sekolah Dasar Volume 2 Nomor 2 Tahun 2014.

Lindawati, S. (2011). Pembelajaran Matematika Dengan Pendekatan Inkuiri Terbimbing Untuk Meningkatkan Kemampuan Pemahaman Dan Komunikasi Matematis Siswa Sekolah Menengah Pertama. Jurnal Pendidikan Matematika Volume 2 Nomor 2 Tahun 2011.

Mariya, Et al. (2013). Keefektifan Pembelajaran Savi Berbantuan Alat Peraga Terhadap Kemampuan Pemecahan Masalah. Jurnal Pendidikan Matematika Volume 2 Nomor 2 Bulan Maret 2013.

Mawaddah, S. \& Maryanti, R. (2016). Kemampuan Pemahaman Konsep Matematis Siswa SMP Dalam Pembelajaran Menggunakan Model Penemuan Terbimbing (Discovery Learning). Jurnal Pendidikan Matematika Volume 4 Nomor 1 Bulan April 2016, hlm 76-85.

Meier, D. (2002). The Accelerated Learning Handbook (diterjemahkan oleh: Rahmani Astuti). Bandung: Kaifa. 
Mulyani, Et al. (2017). Pengaruh Model Pembelajaran Connected Mathematics Project Terhadap Kemampuan Pemahaman Konsep Dan Penalaran Matematis Di Madrasah Aliyah. Jurnal Pendidikan Matematika Raflesia Volume 2 Nomor 1 Tahun 2017.

Purwasih, R. (2015). Peningkatan Kemampuan Pemahaman Matematis Dan Self Confidence Siswa Mts Di Kota Cimahi Melalui Model Pembelajaran Inkuiri Terbimbing. Jurnal Ilmiah Volume 9 Nomor 1 Bulan Maret 2015.

Putra, G. P. (2017). Eksperimentasi Pendekatan Kontekstual Bebantuan Hands On Activity (HoA) Terhadap Kemampuan Pemecahan Masalah Matematik Jurnal Pendidikan Matematika, Volume 8 Nomor 1 Tahun 2017, hlm 73-80.

Ramdani, et al. (2015). Keefektifan Model Dengan Mind Map Melalui Hands On Activity Terhadap Kemampuan Berpikir Kreatif Siswa. Jurnal Pendidikan Matematika Unnes Volume 4 Nomor 2 Bulan Agustus 2015.

Rusyda, N. A. \& Sari, D. S. (2017) Pengaruh Penerapan Model Contextual Teaching and Learning Terhadap Kemampuan Pemahaman Konsep Matematis Siswa SMP Pada Materi Garis dan Sudut. Jurnal Nasional Pendidikan Matematika Volume 1 Nomor 1 Hlm 150 Bulan Maret 2017.

Sucini, E. (2006). Peningkatan Pemahaman Siswa Tentang Keliling dan Luas Lingkaran Melalui Penerapan Model Gal'perin dengan Pendekatan Kontekstual. Jurnal Edusaintek. 2. (Juli 2006). Yogyakarta: Penerbit Andi.

Suherman, H. E. (2003). Pendekatan Kontekstual dalam Pemeblajaran Matematika. Educare, Vol. 2, No.1, Agustus 2003

Sulianto, J. (2011). Keefektifan Model Pembelajaran Kontekstual Dengan Pendekatan Open Ended Dalam Pemecahan Masalah. Jurnal Ilmu Pendidikan, Jilid 17, Nomor 6, Oktober 2011, hlm. 454-458

Susilo B. E. \& Siswoyuono A. M. (2016). Komparasi Pembelajaran SAVI Dan REACT Pada Kemampuan Pemecahan Masalah Siswa Kelas-Viii Materi Kubus Dan Balok. Jurnal Tadris Matematika Volume 2 Nomor 1 Mei 2016, hlm. 15-33

Sutisna, A.P., Maulana, M., Subarjah, H. (2016) Meningkatkan Pemahaman Matematis Melalui Pendekatan Tematik Dengan RME. Jurnal Pena Ilmiah Volume 1 Nomor 1 Tahun 2016.

Uki, et al. (2017). Pengaruh Model Pembelajran Generatif Berbasis Hands On Activity Pada Materi Fluida Dinamis terhadap Kemampuan Berpikir Kritis. Jurnal Pendidikan Fisika UNNES Volume 2 Nomor 1 Tahun 2017. 